\title{
A dengue receptor as possible genetic marker of vector competence in Aedes aegypti Ricardo F Mercado-Curiel ${ }^{1}$, William C Black IV² and Maria de L Muñoz*1
}

\begin{abstract}
Address: ${ }^{1}$ Department of Genetics and Molecular Biology, Centro de Investigación y de Estudios Avanzados del Instituto Politécnico Nacional. Ave. Instituto Politécnico Nacional 2508 Col San Pedro Zacatenco, C.P. 07360, México, DF, México and ²Department of Microbiology, Colorado State University, Fort Collins 80523, USA
\end{abstract}

Email: Ricardo F Mercado-Curiel - rfmcmx@yahoo.com.mx; William C Black -wcb4@lamar.colostate.edu; Maria de L Muñoz* - lmunoz@cinvestav.mx

* Corresponding author

Published: 15 July 2008

BMC Microbiology 2008, 8: II8 doi:10.1 I86/I47I-2/80-8-II8

This article is available from: http://www.biomedcentral.com/I47I-2I80/8/II8

(c) 2008 Mercado-Curiel et al; licensee BioMed Central Ltd.

This is an Open Access article distributed under the terms of the Creative Commons Attribution License (http://creativecommons.org/licenses/by/2.0), which permits unrestricted use, distribution, and reproduction in any medium, provided the original work is properly cited.

\begin{abstract}
Background: Vector competence refers to the intrinsic permissiveness of an arthropod vector for infection, replication and transmission of a virus. Notwithstanding studies of Quantitative Trait Loci (QTL) that influence the ability of Aedes aegypti midgut (MG) to become infected with dengue virus (DENV), no study to date has been undertaken to identify genetic markers of vector competence. Furthermore, it is known that mosquito populations differ greatly in their susceptibility to flaviviruses. Differences in vector competence may, at least in part, be due to the presence of specific midgut epithelial receptors and their identification would be a significant step forward in understanding the interaction of the virus with the mosquito. The first interaction of DENV with the insect is through proteins in the apical membrane of the midgut epithelium resulting in binding and receptormediated endocytosis of the virus, and this determines cell permissiveness to infection. The susceptibility of mosquitoes to infection may therefore depend on their specific virus receptors. To study this interaction in Ae. aegypti strains that differ in their vector competence for DENV, we investigated the DS3 strain (susceptible to DENV), the IBO-I I strain (refractory to infection) and the membrane escape barrier strain, DMEB, which is infected exclusively in the midgut epithelial cells.
\end{abstract}

Results: (I) We determined the MG proteins that bind DENV by an overlay protein binding assay (VOPBA) in Ae. aegypti mosquitoes of the DS3, DMEB and IBO-II strains. The main protein identified had an apparent molecular weight of $67 \mathrm{kDa}$, although the protein identified in the IBO-II strain showed a lower mass $(64 \mathrm{kDa})$. (2) The midgut proteins recognized by DENV were also determined by VOPBA after two-dimensional gel electrophoresis. (3) To determine whether the same proteins were identified in all three strains, we obtained polyclonal antibodies against R67 and R64 and tested them against the three strains by immunoblotting; both antibodies recognized the 67 and $64 \mathrm{kDa}$ proteins, corroborating the VOPBA results. (4) Specific antibodies against both proteins were used for immunofluorescent location by confocal microscopy; the antibodies recognized the basal lamina all along the MG, and cell membranes and intercellular spaces from the middle to the end of the posterior midgut (PPMG) in the neighborhood of the hindgut. (5) Quantitative analysis showed more intense fluorescence in DS3 and DMEB than in IBO-II. (6) The viral envelope antigen was not homogeneously distributed during MG infection but correlated with MG density and the distribution of R67/R64.

Conclusion: In this paper we provide evidence that the $67 \mathrm{kDa}$ protein (R67/R64), described previously as a DENV receptor, is related to vector competence in Ae. aegypti. Consequently, our results strongly suggest that this protein may be a marker of vector competence for DENV in Ae. aegypti mosquitoes. 


\section{Background}

DENV is a Flavivirus within the Arboviruses class, more than 500 of which have so far been identified. DENV is distributed worldwide in tropical and subtropical countries in association with its mosquito vector Ae. aegypti. Dengue infection ranges from self-limited asymptomatic or mild illness (dengue fever, DF) to a severe hemorrhagic disease (dengue hemorrhagic fever, DHF) that can progress to dengue shock syndrome (DSS) characterized by circulatory failure [1].

More than fifty million dengue infection cases occur every year [2], resulting in approximately 24,000 deaths due to DSS. In Mexico [3], 45,748 cases of DF and 10,501 of DHF were reported from 2004 to 2006. Although DEN is the most common vector-borne viral disease, few studies have investigated the complex relationship between DENV and Ae. aegypti through their genetic characteristics.

Transmission of infection depends on DENV virulence, host immunity and the susceptibility of the mosquito to infection. Susceptibility will depend on the interaction between the mosquito and DENV: the interaction between midgut (MG) cell membrane receptors and the virus envelope glycoprotein is the initial step [4] in receptor-mediated endocytosis $[5,6]$. This essential step determines cell permissiveness to infection. Furthermore, it is known that populations of Ae. aegypti differ greatly in their susceptibility to DENV [7-10] and this variability is determined by the effects of several genes $[11,12]$. It has also been proposed [7] that the infection barriers in the mosquitoes are the MG infection barrier (MIB), which prevents DENV infection of MG epithelial cells, and the MG escape barrier (MEB), which prevents DENV from leaving the MG and infecting peripheral tissues, limiting the infection to MG cells. Three Ae. aegypti strains differing in DENV vector competence were selected: the susceptible DS3 strain lacks MIB and MEB, so 95-100\% of these mosquitoes have disseminated infection [13]; the DMEB strain has MEB, and although $85 \%$ of them are infected in the MG epithelial cells, 27\% develop a disseminated infection [13]; and the refractory strain, IBO-11, has MIB [14]. Differences in vector competence may, at least in part, be due to the presence of specific MG epithelial receptors and their identification would be a significant step forward in understanding the interaction of the virus with the mosquito vector with possible implications for vector surveillance and control of virus transmission.

Fc gamma receptor-mediated entry of infectious DENV immune complexes into human monocytes/macrophages is hypothesized to be a key event in the pathogenesis of DHF [15-18]. However, this mechanism does not explain virus entry in primary infections or in cells with non-Fc receptors such as those of mosquitoes $[19,20]$.
Putative non-Fc gamma receptors differ in chemical structure [21]; proteins [22-34] or glycoproteins [35]; heparan sulfates [36] and LPS/CD14-associated binding proteins [37] have been proposed as cellular receptors for DENV. We have previously shown that the four serotypes of DENV mainly recognize two proteins with apparent molecular weights of 80 and $67 \mathrm{kDa}[24,29]$ from $A e$. albopictus $\mathrm{C6} / 36$ cells and Ae. aegypti MG. Although a variety of receptors have been described in many studies, the mechanism by which the virus enters the cell is unknown.

A study of receptors in the DS3, DMEB and IBO-11 strains will allow us to determine whether they are related to the susceptibility of Ae. aegypti to DENV infection and transmission, and consequently whether they may serve as genetic markers of vector competence. To date, none have been described. Knowledge of one or more genes responsible for susceptibility will help in designing new control strategies that may prevent DENV infection and dissemination in the mosquito vector [38].

Therefore, the objective of this work was to determine whether DENV receptors from Ae. aegypti MG are related to vector competence. The aim was to identify the proteins recognized by DENV in three Ae. aegypti strains that differ in their susceptibility to infection.

\section{Results \\ Identification of DENV binding proteins in MG from DS3, DMEB and IBO-I I by VOPBA}

To determine the apparent molecular weights of DENVbinding MG proteins from each Ae. aegypti strain, equivalent amounts of MG protein extracts $(35 \mu \mathrm{g})$ were separated by SDS-PAGE, blotted on to PVDF membranes and analyzed by VOPBA (Figure 1A) using the same specific antibodies against dengue virus used in our previous study [29]. In the IBO-11 strain, DENV bound mainly to a protein of apparent molecular weight about $64 \mathrm{kDa}$, whereas in the DS3 and DMEB strains the apparent molecular mass of this protein was $67 \mathrm{kDa}$. Proteins with molecular masses of 80 and $57 \mathrm{kDa}$ were also visualized, as previously described [29], though these bands were not very strong. Because the IBO-11 strain showed a very faint band, we repeated the experiment, increasing the protein concentration approximately 3-fold compared to DMEB (Figure 1B). The masses of protein loaded on to the gel for each strain were: $72 \mu \mathrm{g}$ for DS3, $59 \mu \mathrm{g}$ for DMEB and 155 $\mu \mathrm{g}$ for $I B O-11$. DENV recognized the protein with apparent molecular mass of $80 \mathrm{kDa}$ with approximately the same intensity in all three strains; the $67 \mathrm{kDa}$ protein had the same molecular weight in the DS3 and DMEB strains, but in the IBO-11 strain the apparent molecular mass was $64 \mathrm{kDa}$. As a control for gel loading accuracy, blots were probed with anti-actin antibody; each specific band on the membranes was quantified by densitometry and nor- 


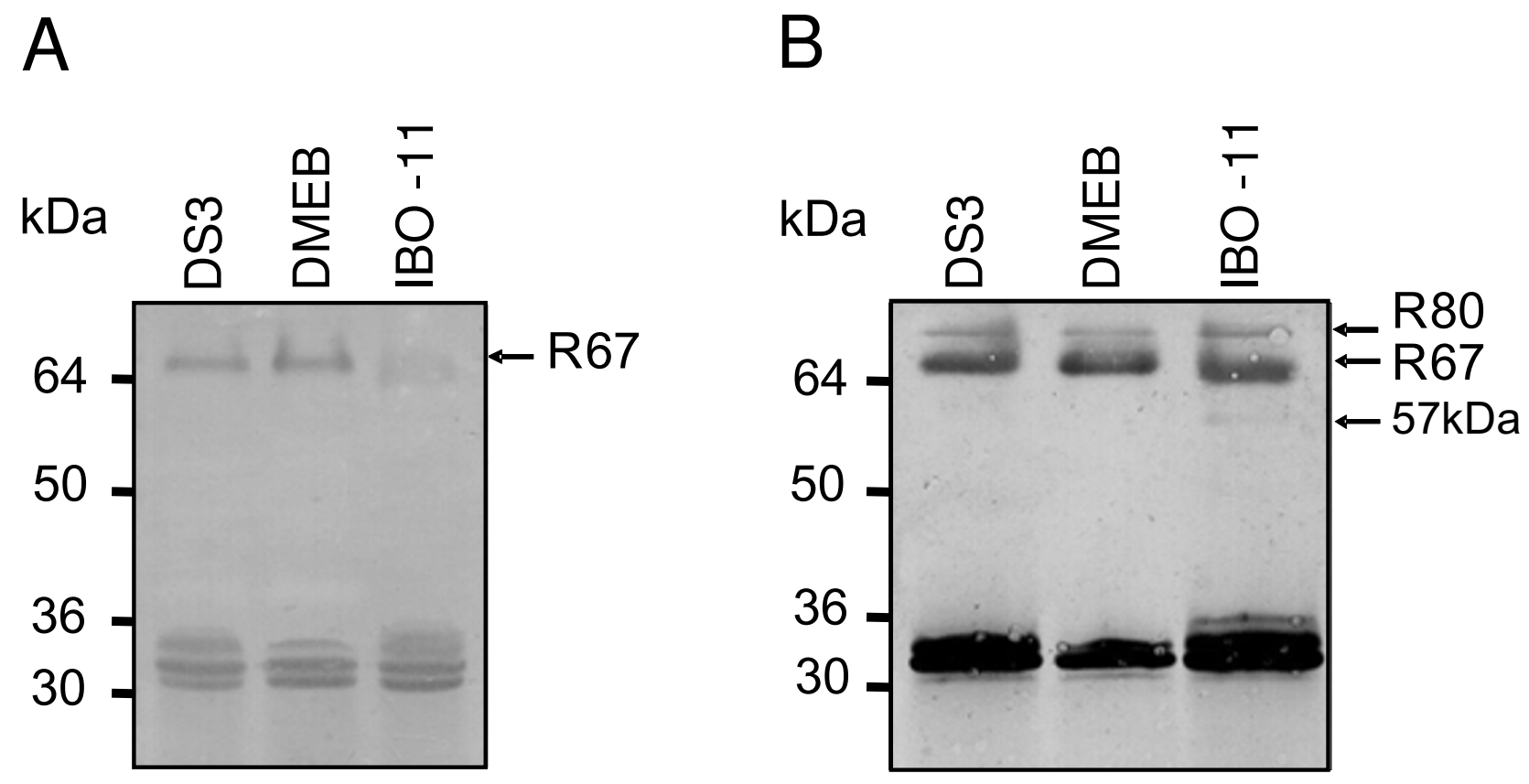

\section{Figure I}

VOPBA of membranes blotted from SDS-PAGE of MG protein extract from DS3, DMEB and IBO-I I strains. A. $35 \mu \mathrm{g}$ of protein were loaded on each lane; actin was used as control for the amount of protein loaded. B. The amounts of protein loaded on each lane were: $72 \mu \mathrm{g}$ for DS3; $59 \mu \mathrm{g}$ for DMEB; I $55 \mu \mathrm{g}$ for IBO-II.

malized to actin. The amount of DENV bound to the 67/ $64 \mathrm{kDa}$ proteins in each strain varied in the proportions DMEB: DS3: IBO-11 = 77: 56: 1 . These differences may be due to differences in the amount of MG protein from each mosquito strain or in their affinity for DENV.

To determine whether the proteins identified by VOPBA represent one or more different molecules or whether there are differences among the strains, 300 MGs were subjected to two-dimensional gel electrophoresis (Figure $2 \mathrm{~A}$ ) and a VOPBA was performed on the gel (Figure 2B). In the DS3 and DMEB strains, DENV mainly recognized two protein spots with almost the same apparent molecular mass of $67 \mathrm{kDa}$ (black arrow). The IBO-11 strain displayed the same spots, although the lower one, which was more evident, probably corresponds to the protein with apparent molecular mass about $64 \mathrm{kDa}$. The faint upper spot may correspond to the protein with molecular mass of $67 \mathrm{kDa}$. The isoelectric point of both proteins in the three strains was about 5.3.

\section{Identification of R67 and R64 in DS3, DMEB and IBO-I I by immunoblotting}

To determine whether the 67 and $64 \mathrm{kDa}$ MG proteins from the three Ae. aegypti strains are related, we obtained specific polyclonal antibodies against those proteins from the DS3 and $I B O-11$ strains and used them for immunoblotting of SDS-PAGE. Both the 67 and $64 \mathrm{kDa}$ proteins were recognized by the antibodies. Figure 3 shows an immunoblot with the specific antibody against R64 from the IBO-11 strain; equivalent results were observed when we used the other antibodies. The main protein recognized by the antibodies in DS3 and DMEB had an apparent molecular weight of $67 \mathrm{kDa}$. The IBO-11 strain displayed a protein with apparent molecular weight of 64 $\mathrm{kDa}$, although the band was very faint, probably because its relative concentration was lower than in the other two strains.

Thus, we found that the differences observed by VOPBA (Figure 1A) were not due to differences in the affinity of R67 and R64 for DENV, but may have been due to differences in the amounts of R67 and R64 in MG from each strain. Each specific band in the membranes was analyzed by densitometry and normalized to actin as control of the quantity of protein loaded on to each lane.

\section{Distribution of R67/R64 in Aedes aegypti midgut}

To determine the distribution of R67 and R64 along the MG in the DS3, DMEB and IBO-11 strains, we performed confocal microscopy on dissected MG, immunofluorescently labeled with the specific antibody against those 


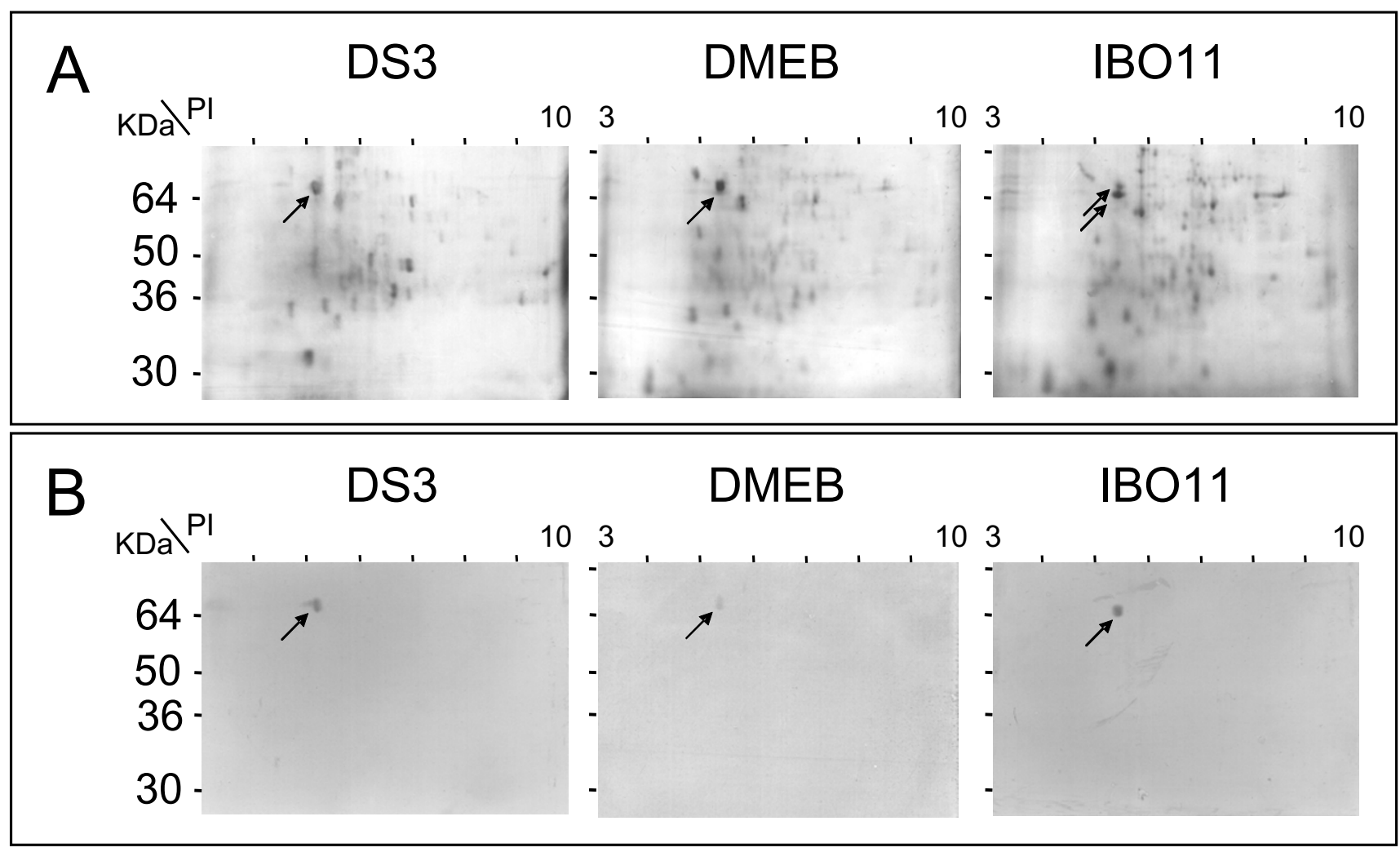

\section{Figure 2}

Two dimensional gel electrophoresis analysis of proteins from DS3, DMEB and IBO-II strains. A. Two dimensional gel electrophoresis of DS3, DMEB and IBO-II protein extracts $(300 \mu \mathrm{g})$. B. VOPBA of PVDF membranes blotted from two dimensional gel electrophograms of MG protein extracts from these strains. Black arrows indicate the dots that were recognized by DENV.

proteins (Figure 4). This revealed the distribution of the proteins between the cells facing the lumen and the basal lamina (BL) of the epithelium, and from the cardia through the anterior MG (AMG) and posterior MG (PMG). The proteins were detected in the BL all along the MG in all three Ae. aegypti strains (evident in panels 4B, $4 \mathrm{D}$ and $4 \mathrm{H}$ ). In addition, the specific antibody bound to epithelial cells beside the cell membrane in all strains from the middle to the end of the PMG (pPMG); in this region the fluorescence was more intense in DS3 and DMEB MGs (4C, 4F) than in IBO-11 MG (4I). These results suggest a higher density of R67 and R64 in DS3 and $D M E B$ MGs. Control MGs stained with pre-immune serum showed no-fluorescence (results not-shown).

Time-course of DENV infection in Aedes aegypti midgut We analyzed the time-course of infection all along the MG in order to determine the density and distribution of DENV and its binding proteins at the outset of the infective process.
Mosquitoes were infected via an artificial membrane feeder and the entire MG was dissected at 5, 13, $26 \mathrm{~h}$ and 14 days of cultivation after infection. The MG was examined from the cardia through the AMG and PMG by confocal microscopy after immunofluorescent labeling with anti-DEN-2 protein E. Figures 5, 6 and 7 correspond to the DS3, DMEB and IBO-11 strains respectively.

DENV reached the epithelial cells in all strains $5 \mathrm{~h}$ after infection, before the peritrophic matrix (PM) was formed. The distribution of DENV in the IBO-11 strain was similar to the other strains until $5 \mathrm{~h}$, but virus density decreased with incubation time; the fluorescence had very low intensity at $13 \mathrm{~h}$ after infection; and at $26 \mathrm{~h}$ and 14 days after infection it had completely disappeared in $80 \%$ of the analyzed MGs.

In the DS3 and DMEB strains the fluorescence was very similar in each region analyzed at all times after infection; the infection increased with time and viral envelope antigen was apparent in the BL from $5 \mathrm{~h}$ until 14 days after 


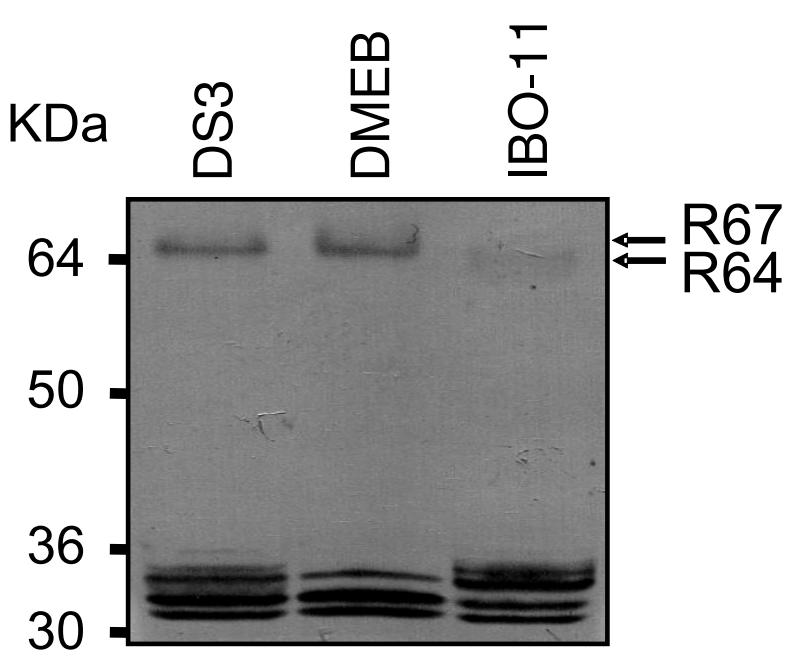

\section{Figure 3}

Immunoblotting with the specific anti-R67 or antiR64 antibody. Protein extracts of Ae. aegypti MG from the DS3, DMEB and IBO- I I strains were separated by SDS-PAGE, transferred to PVDF membranes and immunoblotted with the specific anti-R64 antibody from IBO-II. Actin was used as control of the amount of protein loaded on each lane. Similar results were observed when anti-R67 from IBO-I I or antiR67 or anti-R64 from DS3 was used.

infection irrespective of the distribution in epithelial cells (evident in panel 5J).

We quantified the fluorescence (Figure 8) as mentioned in methods and noticed that the initial level was very similar in all three strains. In DS3 and DMEB the maximum level was very alike, containing no statistically significant difference after $26 \mathrm{~h}$ of infection at pPMG; after 14 days, this region showed less viral envelope antigen and virus was observed at the anterior PMG. Virus infection was higher at this time compare to infection after $5 \mathrm{~h}(\mathrm{p}<0.05)$. If we compare virus infection of IBO-11 strain with DS3 or $D M E B$ at 13, 26 and $336 \mathrm{~h}$ the difference is very evident $\left({ }^{*} \mathrm{p}<0.05\right)$; contrary to infection at $5 \mathrm{~h}$. Furthermore, if we compare, infection at $5 \mathrm{~h}$ with all times in each strain, we observe that DS3 and DMEB showed an increase $\left({ }^{* *} \mathrm{p}\right.$ $<0.05)$; opposite to the IBO-11 strain where there is an infection decrease $\left({ }^{* *} \mathrm{p}<0.05\right)$.

Importantly, the highest fluorescence intensity observed in the MG at the beginning of infection (26 h after infection) was very similar to that observed by immunofluorescence assays using anti-R67/R64 antibody. All infected or non-infected MGs stained with pre-immune serum showed no-fluorescence (results not-shown).

\section{Discussion}

The relationships between DENV and its arthropod vector Ae. aegypti are crucial, and analysis of host cell responses to flavivirus infection of mosquito vectors is particularly important for understanding the maintenance and transmission of the disease. Mosquito populations differ in their susceptibility to flavivirus development, termed "vector competence", reflecting the different barriers encountered by the virus from its entry into the mosquito to its release in the saliva. Factors such as specific mosquito receptors on the epithelial cells as well as differential viral replication in the mosquito are critical for vector competence in addition to other genes as has been exhibited by the QTL studies [39]. In the laboratory we have three mosquito strains with different susceptibilities to DENV infection (DS3, DMEB and IBO-11) and these have allowed us to determine whether MG cell receptors for DENV may be markers of vector competence.

A possible explanation for the wide spectrum of DENV receptors in host cells may be that different cell types have been used; alternatively, the reported proteins may not all be cell membrane components. Increasing evidence $[33,40]$ suggests that DENV interacts differently with mammalian and mosquito cells; accordingly, we have studied the molecules that serve as true DENV receptors in the MG of Ae. aegypti. We previously showed by VOPBA [29] that the four serotypes of DENV mainly recognized two membrane proteins with apparent molecular weights of 80 (R80) and 67 (R67) kDa in Ae. albopictus C6/36 cells and Ae. aegypti MG.

Both of these receptors were detected in the MG of strains DS3, DMEB and IBO-11 in this study, although IBO-11 displayed a protein with a slightly lower apparent molecular weight $(64 \mathrm{kDa})$ in addition to the $67 \mathrm{kDa}$ protein, and the quantity of R67 was much lower than in the other two strains. R67 and R64 seem to be the same protein, because both are recognized by polyclonal anti-R67 and anti-R64 antibodies from the DS3 and IBO-11 strains. The size difference was also detected by two dimensional gels (Figure 2). Munoz et al. [24] and Mercado-Curiel et al. [29] showed that anti-R67 antibody inhibited DENV infection more strongly than anti-R80 in C6/36 cells. This is in agreement with the present results, since $\mathrm{R} 80$ was recognized in all three strains with no apparent change, suggesting that although this protein participates in DENV binding; its role may be different. It will be necessary future studies to determine R80 function during mosquito virus infection. Difference between R67 and R64 will be the objective of future studies, since they may be attributable to many facts such as post-translational modifications, different splicing or a deletion in the coding region. 


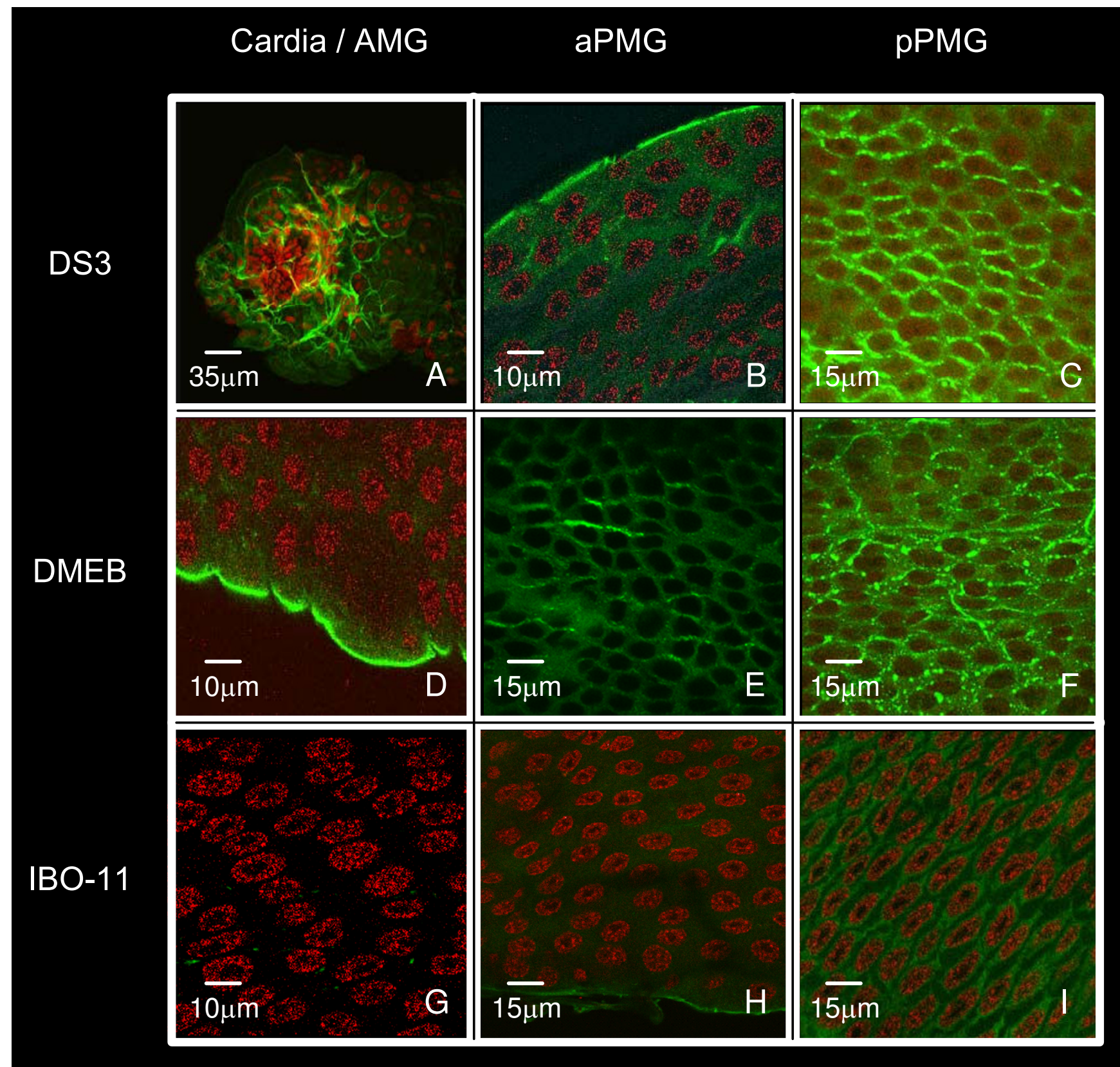

\section{Figure 4}

Immunofluorescence with the specific anti-receptor antibody. MG dissected from the DS3, DMEB and IBO- I/ strains were immunolabeled with the specific anti-R67 antibody from IBO-I I and analyzed by confocal microscopy. Strains: DS3 (panels A, B, C), DMEB (panels D, E, F), IBO-I I (panels G, H, I); analyzed region: cardia/AMG (panels A, D, G), aPMG (panels B, E, H), pPMG (panels C, F, I). AMG (anterior midgut), aPMG (anterior segment of the posterior midgut), pPMG (posterior segment of the posterior midgut).

Studies of the vector competence of Ae. aegypti for DENV are typically qualitative, involving the detection of viral antigens in the MG and the head. This is the first study to scan DENV infection and R67 protein distribution thoroughly along the entire $M G$, taking into account that $M G$ contains morphologically different epithelial cells [41] with different biochemical characteristics [42,43]. Previous studies have not determined DENV distribution in detail; most of them have concerned virus titer (presence or absence) in the whole mosquito MG [44-49]. 


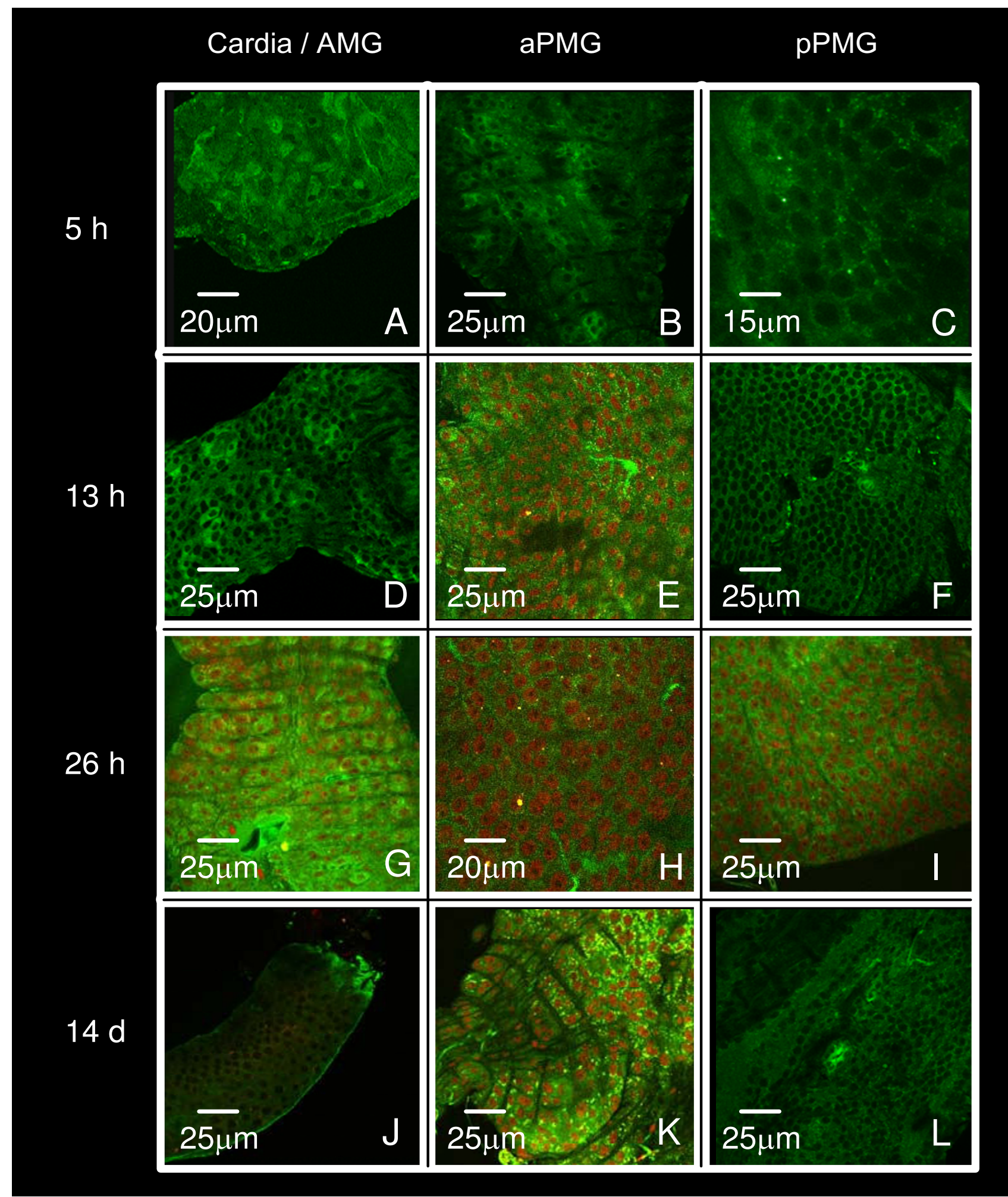

Figure 5

Time-course of midgut DENV infection in Ae. aegypti DS3 strain. Immunofluorescent labelling with the specific antibody anti-DEN-2 protein E was followed by confocal microscopy. MGs were dissected from DS3 mosquitoes 5 , I3, $26 \mathrm{~h}$ and I4 d after infection. Cardia/AMG (panels A, D, G, J), aPMG (panels B, E, H, K), pPMG (panels C, F, I, L). 


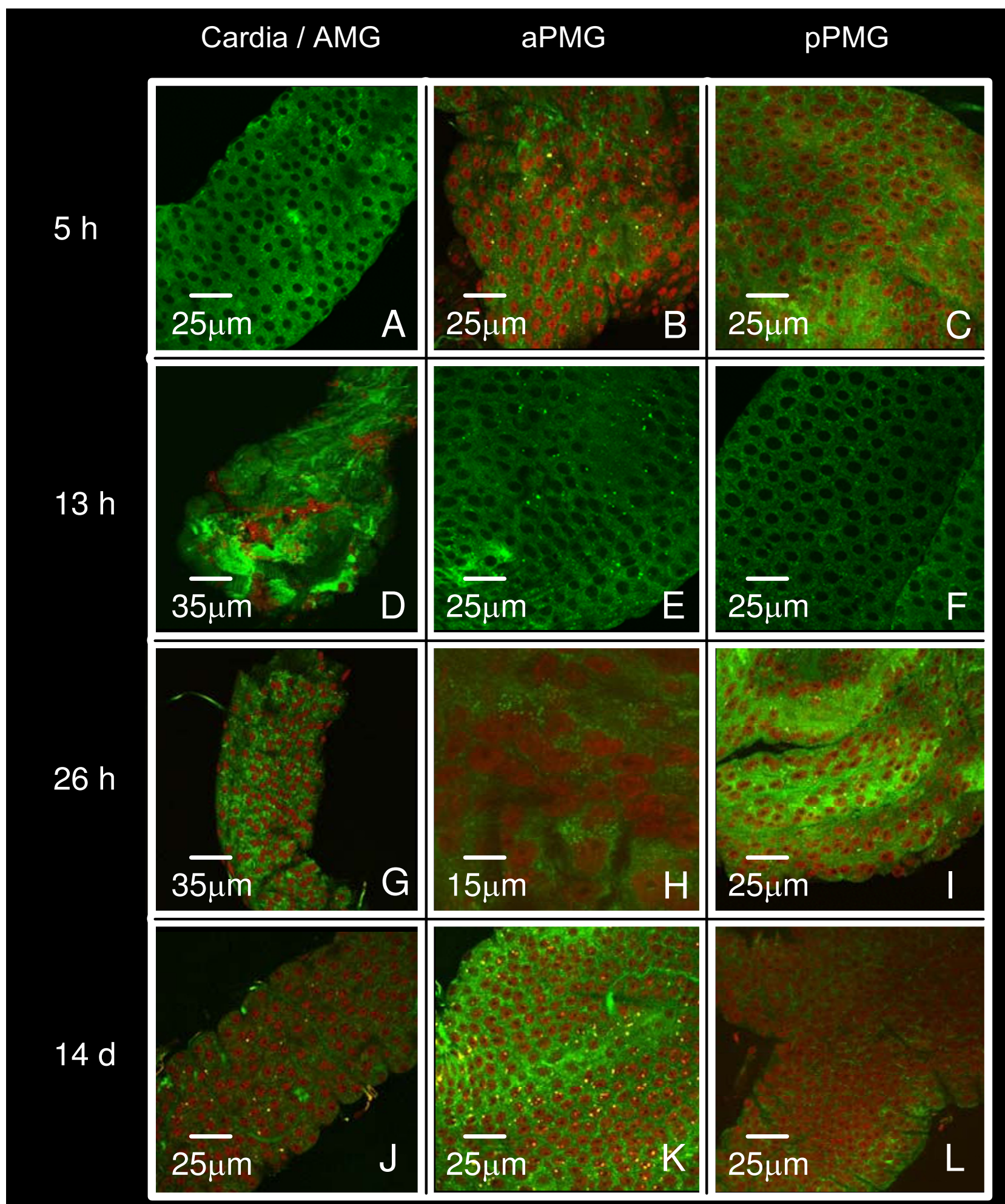

\section{Figure 6}

Time-course of DENV infection in Ae. aegypti midgut (DMEB strain). Immunofluorescent labeling with the specific antibody anti-DEN-2 protein E was followed by confocal microscopy. MGs were dissected from DMEB mosquitoes $5,13,26 \mathrm{~h}$ and I4 d after infection. Cardia/AMG (panels A, D, G, J), aPMG (panels B, E, H, K), pPMG (panels C, F, I L). 


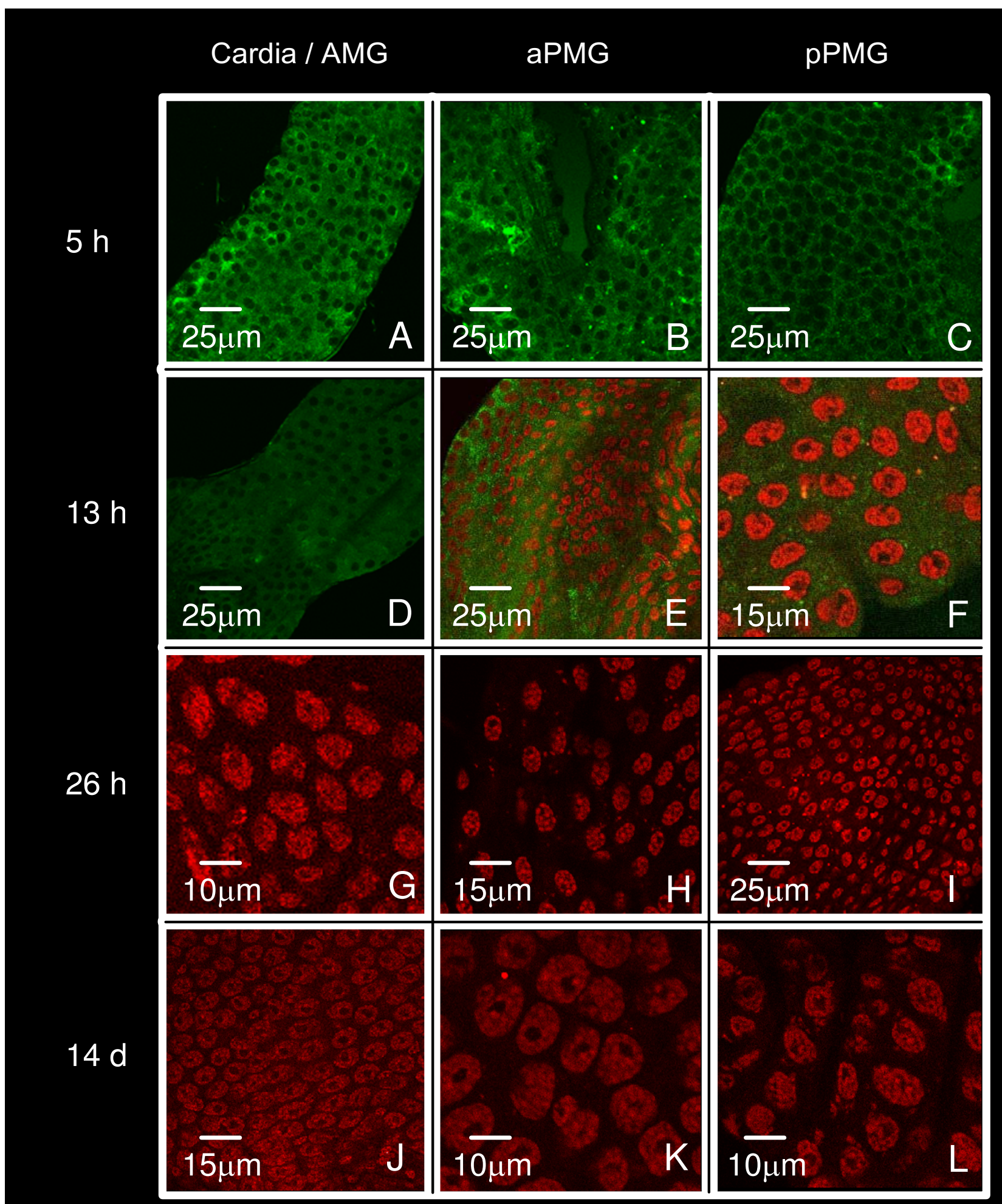

\section{Figure 7}

Time-course of DENV infection in Ae. aegypti midgut (IBO-I I strain). Immunofluorescent labeling with the specific antibody anti-DEN-2 protein $\mathrm{E}$ was followed by confocal microscopy. MGs were dissected from IBO-I I mosquitoes 5 , I 3, $26 \mathrm{~h}$ and $14 \mathrm{~d}$ after infection. Cardia/AMG (panels A, D, G, J), aPMG (panels B, E, H, K), pPMG (panels C, F, I L). 


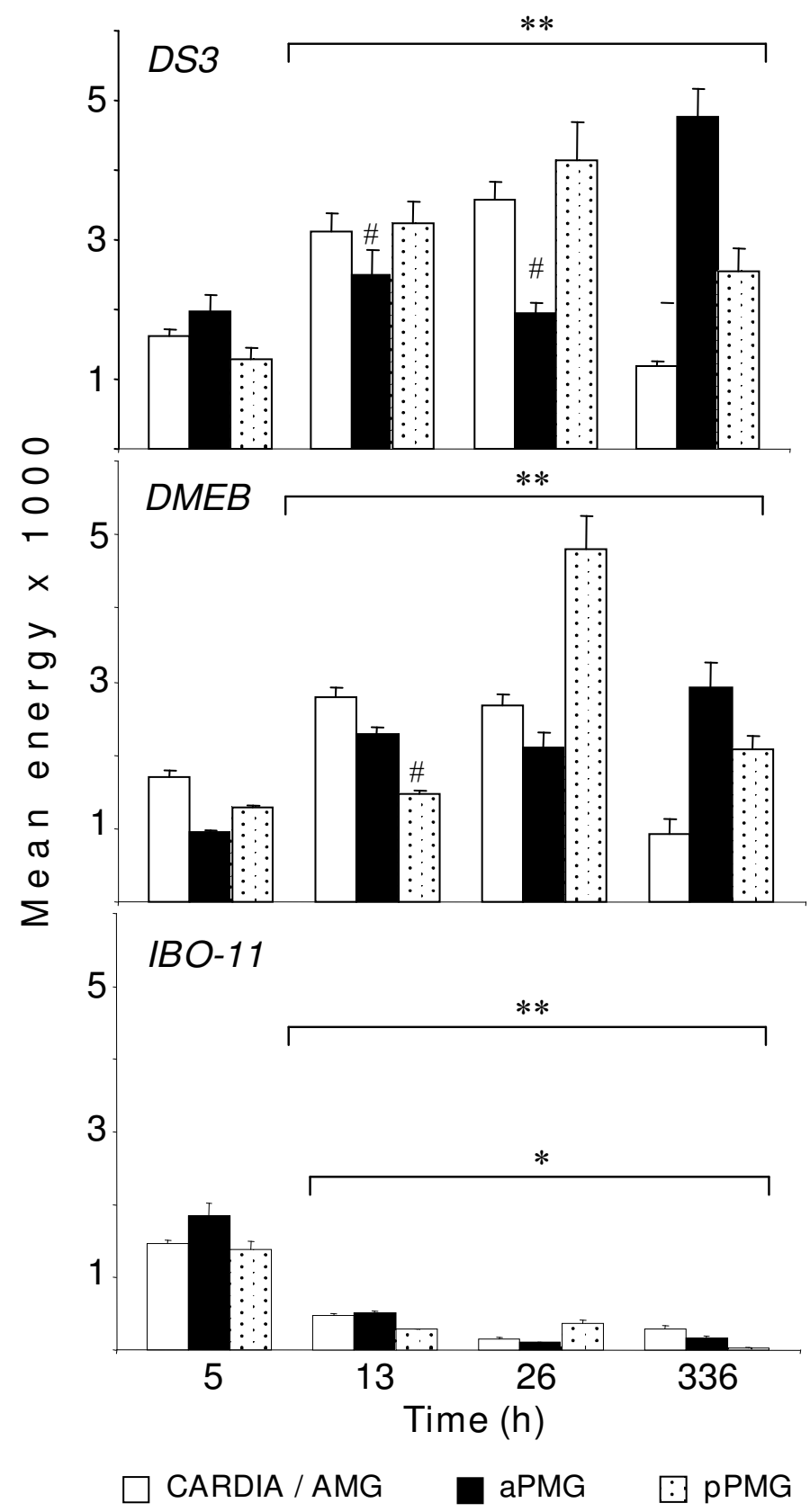

Figure 8

Time-course of DENV infection in Ae. aegypti midgut. Viral envelope antigen distribution during the DENV infection was analyzed in the MG of the DS3 strain (A); DMEB strain (B); or IBO- I I strain (C) in the Cardia/AMG (anterior midgut), aPMG (anterior segment of the posterior midgut), PPMG (posterior segment of the posterior midgut). Values are expressed as the mean \pm S.E.M. ANOVA followed by All Pairwise Multiple Comparison Procedures (Student-Newman-Keuls Method) ( $p<$ $0.05) ; n=4$ independent replications included at least 5 mosquitoes for each strain and each infection time point. Values from DS3 or DMEB strains were compared with IBO- I I strain at I3, 26 and $336 \mathrm{~h}$ in each MG region $(* \mathrm{p}<0.05$, significantly different); Cardia/AMG, aPMG, or PPMG values from DMEB, DS3 or IBO- / / strains at $5 \mathrm{~h}$ post-infection were compared with those post-infected for 13,26 and $336 \mathrm{~h}$ in the respectively strains ( ${ }^{* *} \mathrm{p}<0.05$, significantly different; ${ }^{*} \mathrm{p}>0.05$, non-significantly different). 
R67/R64 were not homogeneously distributed over the epithelial cells along the MG in the three strains; they were mainly present in the cell membrane and behind the intercellular spaces in the region named $\mathrm{PPMG}$, which extends from middle to the end of the posterior MG in the neighborhood of the hindgut. The quantity of R67/R64 in the PPMG region was noticeably higher in DS3 and DMEB than in the IBO-11 strain (Figure 4). The receptor distribution was similar to the distribution of infection at the outset. Moreover, we observed a correlation among receptor abundance, presence of DENV and mosquito strain susceptibility (Figures 4 and 8 ).

Analysis of the time course of DENV infection from the beginning to 14 days gave insight into the earliest events in DENV infection of the MG in the three strains. MG infection diminished by 14 days post-infection, as described previously [47]. We also observed that MGs from the different strains showed a difference in the degree of infection, depending on the susceptibility of the strain. For example, the IBO-11 strain showed almost no fluorescence after 26 days.

Interestingly, DMEB strain showed increase in infection up to the $26 \mathrm{~h}$ in all the three MG regions infection, having the maximal virus accumulation in the PPMG and then diminished by $336 \mathrm{~h}$ post-infection compare to the susceptible strain DS3 that have the maximal virus accumulation in aPMG at 14 days post-infection. These results also display a statistically significative MG infection increase from the first $5 \mathrm{~h}$ post-infection to $26 \mathrm{~h}$ in DS3 and DMEB strains $\left({ }^{* *} \mathrm{p}<0.05\right)$. Moreover, IBO-11 strain exhibited a significative decrease $\left({ }^{* *} p<0.05\right)$ of MG infection from 5 to $336 \mathrm{~h}$ post-infection. Furthermore, virus infection of $I B O-11$ strain was almost completely abolish $\left({ }^{*} \mathrm{p}<0.05\right.$, Figure 8$)$ compared to DS3 and DMEB strains from 13 to $336 \mathrm{~h}$ post-infection.

Recently, the Ae. aegypti genome has been sequenced [50]. This will facilitate the identification of genes encoding the R67/R64 DENV receptors, which could be important for influencing the MG infection barrier (MIB). This is in agreement with Miller and Mitchell [51], who showed that susceptibility, depends on multiple genes. They selected refractory or highly susceptible strains and obtained progeny with intermediate susceptibility, which suggests that alleles at vector competence loci act additively. Bosio et al. [14] proposed a significant additive genetic effect in MIB and demonstrated that the DENV titer in the MG and head did not correlate with the rate of infection. They also showed that the heritability for virus titer in tissues (MG or head) were almost identical in different strains of Ae. aegypti formosus; and showed that the amount of virus in the MG did not determine if virus was disseminated, which hypothetical may be due to the pres- ence or absence of DENV receptors. In the present study we also observed similar maximum levels of DENV in the DS3 and DMEB strains, suggesting that genes that influence the virus titer have minimal impact on overall vector competence.

Further studies are needed to explain the fact that the $D M E B$ strain, which has MEB, showed the presence of DENV in the BL all along the MG throughout the time course examined. The lack of infection in peripheral tissues may have been mainly due to the lack of cell receptors, or to additional factors specific to the kind of cell that allows DENV to infect those organs.

Ae. aegypti seems to be the most vulnerable link in the transmission chain; at present there is no genetic marker of vector competence for DENV. Such a marker would be very important in the design of new mosquito control strategies, such as campaigns focused on natural populations that could be easily identified by their high DENV susceptibility, in order to prevent dengue epidemics.

\section{Conclusion}

Our results may suggest that R67/R64 from the Ae. aegypti MG could be used as a vector competence marker, since those proteins are the main ones involved in the recognition of DENV by MG cells. The amount of these proteins in the MG varied proportionally to mosquito vector competence and their distribution along the MG correlated with the distribution of DENV infection.

\section{Methods \\ Virus}

DEN-2 Jamaica strain was expanded in Vero cells, purified from the culture supernatants as previously described $[52,53]$ and kept frozen at $-70^{\circ} \mathrm{C}$ pending for use. Briefly, Vero cells were cultured at $37^{\circ} \mathrm{C}, 2 \% \mathrm{CO}_{2}$ in Dulbecco's Modified Eagle's Medium (DMEM; HyClone, Logan, Utah, USA) supplemented with 5\% heat-inactivated fetal bovine serum (FBS; Gibco BRL, Gaithersburg, MD, USA), $100 \mathrm{units} / \mathrm{ml}$ of penicillin and $100 \mu \mathrm{g} / \mathrm{ml}$ of streptomycin. Vero cells were infected with $0.2 \mathrm{ml}$ of DEN-2 inoculum with an input MOI of $600 \mathrm{PFU} /$ plate and incubated for 10 days; DEN-2 was purified from the clarified supernatants by a $30 / 60 \%$ sucrose step gradient. Titers of virus stocks made in LLC-MK2 cells [52] were $8 \times 10^{8} \mathrm{PFU} / \mathrm{ml}$.

\section{Mosquito culture}

Mosquitoes (DS3, DMEB and IBO-11 strains) were laboratory-reared and maintained at $28^{\circ} \mathrm{C}$ and $80 \% \mathrm{RH}$ with a $12 \mathrm{~h}$ photoperiod using standard mosquito-rearing procedures [54]. They were fed with blood meals to maintain the strains and the eggs were collected in water cups containing paper filters. 


\section{Mosquito infection and midgut dissection}

Mosquitoes (DS3, DMEB and IBO-11 strains) were infected via an artificial membrane feeder [55]. Briefly, the blood meal consisted of equal parts of virus suspension, washed sheep erythrocytes and FBS in 10\% sucrose. It was incubated at $38^{\circ} \mathrm{C}$ for $15 \mathrm{~min}$, then placed in membrane feeders covered with hog gut and maintained at a constant temperature of $37^{\circ} \mathrm{C}$. Mosquitoes (250, 3-4 days old) were starved of sucrose and deprived of water for 30 hours prior to blood feeding. They were allowed to feed for 4560 minutes. Fully engorged females were selected and held in the insectary.

The entire MG was dissected from 25 mosquitoes at 5, 13, $26 \mathrm{~h}$ and 14 days after feeding. The procedure was carried out in $10 \mu \mathrm{l}$ phosphate buffered saline (PBS). The MG was rinsed twice and resuspended in $10 \mu \mathrm{l}$ of PBS. MGs were immunolabeled with a specific antibody against DEN-2 envelope protein E (anti-DEN-2 protein E).

All experiments included control mosquitoes fed with a blood meal without virus. MGs from non-infected mosquitoes were also used to obtain protein extracts and were examined by immunofluorescence with anti-R67.

\section{DEN-2 affinity chromatography}

Purified DEN-2 was bound covalently to $1 \mathrm{~g}$ CNBr-activated Sepharose $^{\mathrm{TM}} 4 \mathrm{~B}$ (Amersham Pharmacia Biotech) as described previously [29]. The DEN-2-Sepharose $\mathrm{T}^{\mathrm{TM}} 4 \mathrm{~B}$ column was either used immediately or stored in $0.002 \%$ sodium azide at $4^{\circ} \mathrm{C}$ pending for use.

Protein extracts were obtained by homogenizing MGs (300/ml from the DS3 and IBO-11 strains) in buffer E (50 $\mathrm{mM}$ Tris-HCl, pH 7.2, 1 mM EDTA, 0.05\% v/v Triton X100) containing a protease inhibitor cocktail (SigmaAldrich P8340). To obtain the soluble proteins, the homogenate was centrifuged for $10 \mathrm{~min}$ at 10,000 rpm at $4^{\circ} \mathrm{C}$.

Each MG protein extract ( $1 \mathrm{mg}$ ) was applied to the DEN2-Sepharose ${ }^{\mathrm{TM}} 4 \mathrm{~B}$ column $(1 \mathrm{ml})$ equilibrated in buffer $\mathrm{E}$ and washed with the same buffer. The DEN-2 binding proteins were eluted with buffer E containing $0.5 \mathrm{M} \mathrm{NaCl}$. Fractions of $0.5 \mathrm{ml}$ were collected and the protein content was monitored by the Bradford method [56]. The retained and eluted proteins were precipitated with acetone, resuspended in a $10 \mu \mathrm{l}$ buffer $\mathrm{E} /$ protease inhibitor cocktail (Sigma-Aldrich P8340) and analyzed by 10\% sodium dodecylate sulfate polyacrylamide gel electrophoresis (SDS-PAGE) [57].

\section{Preparation of specific polyclonal antibodies against DEN-} 2 protein E, $\mathbf{R 6 7}$ and $\mathbf{R 6 4}$

To obtain specific anti-DEN-2 protein E, 10\% SDS-PAGE was performed with purified DEN-2 and the corresponding $52 \mathrm{kDa}$ band from the silver-stained gel was excised and used to immunize BALB/c mice as described below.

Proteins retained and eluted from the DEN-2-Sepharose ${ }^{\mathrm{TM}}$ $4 \mathrm{~B}$ column were separated by $10 \%$ SDS-PAGE. After silver staining, the 64 or $67 \mathrm{kDa}$ band was excised, cut into small pieces, suspended in PBS and mixed with an equal volume of Titer-Max adjuvant (CytRx Vaxcel Inc., Norcross, $\mathrm{GA}$ ) to immunize two groups of BALB/c mice and obtain specific antibodies against R67 or R64 from DS3 or IBO11 strain Ae. aegypti MGs.

Pre-immune sera were obtained before immunization. The mice received a booster fifteen days after the first immunization. They were bled after thirty days and the sera were stored at $-70^{\circ} \mathrm{C}$ until use. Negative controls using pre-immune sera were included in all assays. All immunofluorescence and immunoblotting results were reproducible using either anti-R67 or R64 from either DS3 or IBO-11.

\section{Immunofluorescence with anti-DEN-2 protein $E$ and anti- R67}

After the MGs were dissected from the different strains and different infection times, including non-infected mosquitoes as negative control; they were fixed for $2 \mathrm{~h}$ in $4 \%$ p-formaldehyde (Sigma-Aldrich Corporation), washed with PBS, $0.2 \%$ PBT (5\% BSA, $0.2 \%$ Triton X-100 in PBS), incubated overnight at $4^{\circ} \mathrm{C}$ with anti-DEN-2 protein $\mathrm{E}$ diluted 1:75 or anti-R67 diluted 1:40, washed with $0.1 \%$ PBT (0.1\% Triton X-100), incubated for $2 \mathrm{~h}$ with 1:500 FITC goat anti/mouse (Zymed Laboratories Inc. S. San Francisco, CA USA), stained with $1 \mu \mathrm{g} / \mathrm{ml}$ propidium iodide (Sigma-Aldrich Corporation), and then washed with $0.1 \%$ PBT. Finally, each MG was placed individually on a glass slide with a Vecta Shield (Vector Laboratories). All preparations were examined by confocal microscopy (TCS SP5 Leica Microsystems).

\section{Confocal microscopy analysis}

Confocal Image was captured using a Leica confocal microscope scanning system. The confocal microscope was set up for all the experiments as follow: speed $400 \mathrm{~Hz}$, PMT1-746, PMT2-933, potency $1 / 3$ and laser 26\%. Fluorescence evaluation was made using a $64 \times$ (NA 0.3 ) objective. The lens is raised to its maximum specified height. The detector is secured on the stage and centered grossly using either laser fluorescent or light. The detector position is then adjusted more accurately to achieve maximum signal intensity by using the microscope's $\mathrm{x} / \mathrm{y}$ joystick. The CLSM zoom factor is set from 8 to 32 to 
reduce the beam scan and to focus it into the "sweet spot" of the detector.

A series of 30 successive sections were recorded along the optical axis of the microscope over a range of the specimen planes with a depth separation of $1 \mu \mathrm{m}$ for each one of the three different MG regions (Cardia/AMG, aPMG, pPMG) and mosquito strains, comprising a total of 3 series of 30 slices. Then each confocal fluorescence images was divided in areas of $1000 \mu \mathrm{m} 2$. This was done for every time and each mosquito strain.

The Leica software (1997-2002, Leica Microsystems Heidelberg $\mathrm{GmbH}$ ) was used to evaluate all images. ANOVA statistic analysis was conducted for all the data.

Results represent the analysis of at least 20 MGs for each infection time and for each mosquito strain in four independent experiments.

\section{Statistical analysis}

The means and standard errors of means (S.E.M.) were calculated for all groups. The data was subjected to a twoway analysis of variance (ANOVA) by General Linear Model followed by All Pairwise Multiple Comparison Procedures (Student-Newman-Keuls Method) to determine whether means were significantly different among them. All P values less than 0.05 were considered to indicate statistical significance. All the statistics were carried out in SigmaStat 2.03 software and data plotted in SigmaPlot 2001.

\section{D gel electrophoresis}

Midguts (300) from each strain were solubilized in $125 \mu \mathrm{l}$ of IPG strip rehydration buffer (8 M urea, 2\% CHAPS, 10 mM DTT, $0.2 \%$ Bio-Lyte) at room temperature and centrifuged at $10,000 \mathrm{rpm}$ for $10 \mathrm{~min}$. The resulting supernatants, containing approximately $936 \mu$ g protein for DS3, $1080 \mu \mathrm{g}$ for DMEB and $1143 \mu \mathrm{g}$ for IBO-11, were used to rehydrate each ReadyStrip IPG, pH range 3-10, 7 cm (BioRad Laboratories, Hercules, CA, USA) under passive conditions overnight at $4{ }^{\circ} \mathrm{C}$ in the focusing tray (MiniPROTEAN 3 cell). Subsequently, IEF was carried out as recommended by the manufacturer $(2 \mathrm{~h}$ at $4000 \mathrm{~V}$ with a gradient until a total of 10000 volt-hour was reached).

The strips were removed from the focusing tray and incubated for $15 \mathrm{~min}$ in $1 \mathrm{ml}$ equilibration buffer I $(50 \mathrm{mM}$ Tris-HCl, $\mathrm{pH} 8.8,6 \mathrm{M}$ urea, $2 \%$ SDS, 30\% glycerol, $1 \%$ DTT) and $15 \mathrm{~min}$ in equilibration buffer II (6 M urea, 0.375 M Tris- $\mathrm{HCl}, \mathrm{pH} 8.8,2 \%$ SDS, $20 \%$ glycerol, $2.5 \% \mathrm{w} /$ $\mathrm{v}$ iodoacetamide). They were washed with distilled water and placed on the top of the second dimension gel $(10 \%$ SDS-PAGE). Molecular weight markers were applied to small pieces of chromatography paper and inserted next to each strip on the top of the gel, then the strips and markers were sealed with ReadyPrep Overlay Agarose $(0.5 \%$ low melting point agarose in $1 \mathrm{X}$ Tris/Glycine/SDS and $0.003 \%$ Bromophenol Blue). The second dimension was developed at a constant $150 \mathrm{~V}$ (Mini Protean 3, BioRad Laboratories, Hercules, CA, USA). The gels were silver stained or used for 2D VOPBA as described below.

\section{ID and 2D virus overlay protein binding assay (VOPBA)}

MG protein extracts $(35 \mu \mathrm{g})$ from each strain, or $72 \mu \mathrm{g}$ for $D S 3,59 \mu \mathrm{g}$ for $D M E B$ and $155 \mu \mathrm{g}$ for $I B O-11$, were obtained as mentioned above by DEN-2 affinity chromatography and separated by $10 \%$ SDS-PAGE. Two dimensional gels were developed with approximately $1000 \mu \mathrm{g}$ protein from MGs of each strain. All the gels were blotted on to polyvinylidine difluoride (PVDF) membranes using the WetBlot technique (BioRad Laboratories, Hercules, CA, USA) in transfer buffer (15.6 mM Tris-HCl, $120 \mathrm{mM}$ glycine, 20\% methanol). After transfer was complete, VOPBA was performed as previously described [24]. Briefly, the membrane was blocked for $1 \mathrm{~h}$ at room temperature with $5 \%$ skim milk in TBS $(100 \mathrm{mM}$ Tris-HCl, $0.15 \% \mathrm{NaCl}$ ), incubated overnight with purified DEN-2, washed with TTBS (100 mM Tris-HCl, $0.15 \% \mathrm{NaCl}, 0.2 \%$ Tween 20) and incubated overnight with 1:200 anti-DEN2 protein $\mathrm{E}$ at $4{ }^{\circ} \mathrm{C}$. Mouse anti-rat brain actin Mab (generously provided by Dr. Manuel Hernandez-Hernandez from the department of Cell Biology, Centro de Investigación y de Estudios Avanzados del IPN, Mexico) diluted 1:50 was also included in the VOPBA from 1D gels. The epitope recognized by this MAb is conserved among all actins. After washing with TTBS, the membrane was incubated for $2 \mathrm{~h}$ at room temperature with 1:1000 alkaline phosphatase (AP) labeled goat anti-mouse (Zymed Laboratories Inc. S. San Francisco, CA USA) and the reactive proteins were visualized by color development with the chromogenic substrate BCIP/NBT.

\section{Immunoblotting with anti-R67 and anti-R64}

MG protein extracts from the DS3, DMEB and IBO-11 strains were separated by $10 \%$ SDS-PAGE, transferred to PVDF membranes (BioRad Laboratories, Hercules, CA, USA) and incubated with anti-R67 or anti-R64 diluted $1: 75$ in TBS ( $100 \mathrm{mM}$ Tris- $\mathrm{HCl}, 0.15 \% \mathrm{NaCl})$. In addition, anti-actin antibodies diluted 1:50 in TBS were used. The membranes were incubated for $2 \mathrm{~h}$ at room temperature with the secondary antibody, AP goat anti-mouse (Zymed Laboratories Inc., San Francisco, CA, USA) diluted 1:1000, and color was developed as recommended by the manufacturer and described above.

\section{Authors' contributions}

RFMC carried out all the experiment assays. MLM, RFMC and WCB participated in the discussion of results. RFMC and MLM contributed to assembling the manuscript. 
MLM proofread the manuscript. All authors participated in the discussion of results, read and approved the final manuscript.

\section{Acknowledgements}

We acknowledge the M. Sc. Maria Leticia Avila Ramirez for statistical analysis. Doctor Alvaro Diaz-Badillo is gratefully acknowledged for their help during the development of this research. This research was supported by the United States Public Health Service Grant Al 45430 sub grant G-4632I.

\section{References}

I. Gubler DJ: Epidemic dengue/dengue hemorrhagic fever as a public health, social and economic problem in the 2 Ist century. Trends Microbiol 2002, 10:100-103.

2. WHO: 2007 [http://www.who.int/csr/disease/dengue/impact/en/].

3. DEGPI (Dirección General de Epidemiología de la Secretaría de Salud): Boletín Epidemiología. 2006 [http:// www.dgepi.salud.gob.mx/boletin/].

4. Hung SL, Lee PL, Chen HW, Chen LK, Kao CL, King CC: Analysis of the steps involved in Dengue virus entry into host cells. Virology 1999, 257:156-167.

5. Heinz FX, Allison SL: Flavivirus structure and membrane fusion. Adv Virus Res 2003, 59:63-97.

6. Rey FA: Dengue virus envelope glycoprotein structure: new insight into its interactions during viral entry. Proc Natl Acad Sci USA 2003, 100:6899-690I.

7. Black WC 4th, Bennett KE, Gorrochotegui-Escalante N, Barillas-Mury CV, Fernandez-Salas I, Munoz ML, Farfan-Ale JA, Olson KE, Beaty BJ: Flavivirus susceptibility in Ae. aegypti. Arch Med Res 2002, 33(4):379-388.

8. Lourenco-de-Oliveira R, Vazeille M, de Filippis AM, Failloux AB: Ae. aegypti in Brazil: genetically differentiated populations with high susceptibility to dengue and yellow fever viruses. Trans $R$ Soc Trop Med Hyg 2004, 98(I):43-54.

9. Bennett KE, Olson KE, Munoz ML, Fernandez-Salas I, Farfan-Ale JA, Higgs S, Black WC 4th, Beaty BJ: Variation in vector competence for dengue 2 virus among 24 collections of Ae. aegypti from Mexico and the United States. Am J Trop Med Hyg 2002, 67(1):85-92

10. Sumanochitrapon $W$, Strickman $D$, Sithiprasasna $R$, Kittayapong $P$, Innis BL: Effect of size and geographic origin of Ae. aegypti on oral infection with dengue-2 virus. Am J Trop Med Hyg 1998, 58:283-286.

II. Gomez-Machorro C, Bennett KE, Muñoz ML, Black WC: Quantitative Trait Loci affecting dengue midgut infection barriers in an advanced intercross line of Ae. aegypti. Insect Mol Biol 2004 I3(6):637-648.

12. Severson DW, Knudson DL, Soares MB, Loftus BJ: Ae. aegypti genomics. Insect Biochem Mol Biol 2004, 34:7I5-72I.

13. Bennett KE, Beaty BJ, Black WC 4th: Selection of D2S3, an Ae. aegypti (Diptera: Culicidae) strain with high oral susceptibility to Dengue 2 virus and D2MEB, a strain with a midgut barrier to Dengue 2 escape. J Med Entomol 2005, 42(2): I I0-II 9.

14. Bosio CF, Beaty BJ, Black WC 4th: Quantitative genetics of vector competence for dengue-2 virus in Ae. aegypti. Am J Trop Med Hyg 1998, 59(6):965-970.

15. Littaua R, Kurane I, Ennis FA: Human IgG Fc receptor II mediates antibody-dependent enhancement of dengue virus infection. J Immunol 1990, |44(8):3183-3186.

16. Daughaday CC, Brandt WE, McCown JM, Russell PK: Evidence for two mechanisms of dengue virus infection of adherent human monocytes: trypsin-sensitive virus receptors and trypsin-resistant immune complex receptors. Infect Immun 1981, 32:469-473.

17. Halstead S: Neutralization and antibody-dependent enhancement of dengue viruses. Adv Virus Res 2003, 60:42I-467.

18. Thullier P, Demangel C, Bedouelle H, Megret F, Jouan A, Deubel V, Mazie JC, Lafaye $P$ : Mapping of a dengue virus neutralizing epitope critical for the infectivity of all serotypes: insight into the neutralization mechanism. J Gen Virol 200I, 82:1885-I892.

19. Bielefeldt-Ohmann H, Meyer M, Fitzpatrick DR, Mackenzie JS: Dengue virus binding to human leukocyte cell lines: receptor usage differs between cell types and virus strains. Virus Res 200I, 73:8I-89.

20. Diamond MS, Edgil D, Roberts TG, Lu B, Harris E: Infection of human cells by dengue virus is modulated by different cell types and viral strains. J Virol 2000, 74:78|4-7823.

21. Anderson R: Manipulation of cell surface macromolecules by flaviviruses. Adv Virus Res 2003, 59:229-274.

22. Jindadamrongwech S, Smith DR: Virus Overlay Protein Binding Assay (VOPBA) reveals serotype specific heterogeneity of dengue virus binding proteins on HepG2 human liver cells. Intervirology 2004, 47(6):370-373.

23. Moreno-Altamirano MM, Sanchez-Garcia FJ, Muñoz ML: Non Fc receptor-mediated infection of human macrophages by dengue virus serotype 2. J Gen Virol 2002, 83(5): I I 23-I I30.

24. Muñoz ML, Cisneros A, Cruz J, Das P, Tovar R, Ortega A: Putative dengue virus receptors from mosquito cells. FEMS Microbiol Lett 1998, 168(2):251-258.

25. Zhang W, Chipman PR, Corver J, Johnson PR, Zhang Y, Mukhopadhyay S, Baker TS, Strauss JH, Rossmann MG, Kuhn RJ: Visualization of membrane protein domains by cryo-electron microscopy of dengue virus. Nat Struct Biol 2003, I O(I I):907-9I2.

26. Reyes-Del Valle J, Chavez-Salinas S, Medina F, Del Angel RM: Heat shock protein 90 and heat shock protein 70 are components of dengue virus receptor complex in human cells. J Virol 2005 , 79(8):4557-4567.

27. Sakoonwatanyoo P, Boonsanay V, Smith DR: Growth and production of the dengue virus in $C 6 / 36$ cells and identification of a laminin-binding protein as a candidate serotype 3 and 4 receptor protein. Intervirology 2006, 49(3): I6I-172.

28. Navarro-Sanchez E, Altmeyer R, Amara A, Schwartz O, Fieschi F, Virelizier JL, Arenzana-Seisdedos F, Despres P: Dendritic-cell-specific ICAM3-grabbing non-integrin is essential for the productive infection of human dendritic cells by mosquitocellderived dengue viruses. EMBO Rep 2003, 4(7):723-728.

29. Mercado-Curiel RF, Esquinca-Avilés HA, Tovar R, Díaz-Badillo A, Camacho-Nuez M, Muñoz ML: The four serotypes of dengue recognize the same putative receptors in Ae. aegypti midgut and Ae. albopictus cells. BMC Microbiology 2006, 6:85

30. Lozach PY, Burleigh L, Staropoli I, Navarro-Sanchez E, Harriague J, Virelizier JL, Rey FA, Despres P, Arenzana-Seisdedos F, Amara A: Dendritic cell-specific intercellular adhesion molecule 3 grabbing non-integrin (DC-SIGN)-mediated enhancement of dengue virus infection is independent of DC-SIGN internalization signals. J Biol Chem 2005, 280(25):23698-23708.

31. Ramos-Castaneda J Imbert JL, Barron BL, Ramos C: 65-kDa trypsin-sensible membrane cell protein as a possible receptor for dengue virus in cultured neuroblastoma cells. J Neurovirol 1997, 3:435-440.

32. Salas-Benito JS, Del Angel RM: Identification of two surface proteins from C6/36 cells that bind dengue type 4 virus. IViro 1997, 7 I ( I 0):7246-7252.

33. Thaisomboonsuk BK, Clayson ET, Pantuwatana S, Vaughn DW, Endy TP: Characterization of dengue-2 virus binding to surfaces of mammalian and insect cells. Am J Trop Med Hyg 2005, 72(4):375-383

34. Tassaneetrithep B, Burgess TH, Granelli-Piperno A, Trumpfheller C Finke J, Sun W, Eller MA, Pattanapanyasat K, Sarasombath S, Birx DL, Steinman RM, Schlesinger S, Marovich MA: DC-SIGN (CD209) mediates dengue virus infection of human dendritic cells. Exp Med 2003, 197(7):823-829.

35. Marianneau P, Megret F, Olivier R, Morens DM, Deubel V: Dengue I virus binding to human hepatoma HepG2 and simian Vero cell surfaces differs. J Gen Virol 1996, 77( I 0):2547-2554.

36. Chen Y, Maguire T, Hileman RE, Fromm JR, Esko JD, Linhardt RJ, Marks RM: Dengue virus infectivity depends on envelope protein binding to target cell heparan sulfate. Nat Med 1997, 3(8):866-87I.

37. Chen YC, Wang SY, King CC: Bacterial lipopolysaccharide inhibits dengue virus infection of primary human monocytes/ macrophages by blockade of virus entry via a CDI4-dependent mechanism. J Virol 1999, 73(4):2650-2657.

38. Kramer LD, Ebel GD: Dynamics of flavivirus infection in mosquitoes. Adv Virus Res 2003, 60:187-232.

39. Bosio CF, Fulton RE, Salasek ML, Beaty BJ, Black WC IV: Quantitative trait loci that control vector competence for dengue-2 virus in the mosquito Ae. aegypti. Genetics 2000, 156:687-698. 
40. Bryant JE, Calvert AE, Mesesan K, Crabtree MB, Volpe KE, Silengo S, Kinney RM, Huang CYH, Miller BR, Roehrig JT: Glycosylation of the dengue 2 virus E protein at N67 is critical for virus growth in vitro but not for growth in intrathoracically inoculated Ae. aegypti mosquitoes. Virology 2007. doi: 10.1016/ j.virol.2007.05.007

41. Zieler H, Garon CF, Fischer ER, Shahabuddin M: A tubular network associated with the brush-border surface of the Ae. aegypti midgut: implications for pathogen transmission by mosquitoes. J Exp Biol 2000, 203:1599-16II.

42. Shahabuddin M, Pimenta PF: Plasmodium gallinaceum preferentially invades vesicular ATPase-expressing cells in Ae. aegypti midgut. Proc Natl Acad Sci USA 1998, 95:3385-3389.

43. Shahabuddin M, Costero A: Spatial distribution of factors that determine sporogonic development of malaria parasites in mosquitoes. Insect Biochem Mol Biol 200I, 3 I (3):23I-240.

44. Gubler DJ, Rosen L: Variation among geographic strains of Aedes albopictus in susceptibility to infection with dengue viruses. Am J Trop Med Hyg 1976, 25:318-325.

45. Miller BR, Mitchell C]: Genetic selection of a flavivirus refractory strain of the yellow fever mosquito Ae. aegypti. Am J Trop Med Hyg 199I, 45:399-407.

46. Myles KM, Pierro DJ, Olson KE: Deletions in the putative cell receptor-binding domain of sindbis virus strain MREI6 E2 glycoprotein reduce midgut infectivity in Ae. aegypti. J Virol 2003, 77(16):8872-888I.

47. Salazar MI, Richardson JH, Sanchez-Vargas I, Olson KE, Beaty BJ: Dengue virus type 2: replication and tropisms in orally infected Ae. aegypti mosquitoes. BMC Microbiology 2007, 7:9.

48. Richardson J, Molina-Cruz A, Salazar MI, Black W IV: Quantitative analysis of dengue-2 virus RNA during the extrinsic incubation period in individual Ae. aegypti. Am J Trop Med Hyg 2006, 74(I): $|32-14|$.

49. Molina-Cruz A, Gupta L, Richardson J, Bennett K, Black W IV, Barillas-Mury $C$ : Effect of mosquito midgut trypsin activity on dengue-2 virus infection and dissemination in Ae. aegypti. Am Trop Med Hyg 2005, 72(5):63 I-637.

50. Nene V, Wortman JR, Lawson D, Haas B, Kodira C, Tu ZJ, Loftus B, Xi Z, Megy K, Grabherr M, Ren O, Zdobnov EM, Lobo NF, Campbell KS, Brown SE, Bonaldo MF, Zhu J, Sinkins SP, Hogenkamp DG, Amedeo P, Arensburger P, Atkinson PW, Bidwell S, Biedler J, Birney E, Bruggner RV, Costas J, Coy MR, Crabtree J, Crawford M, Debruyn B, Decaprio D, Eiglmeier K, Eisenstadt E, El-Dorry H, Gelbart WM, Gomes SL, Hammond M, Hannick LI, Hogan JR, Holmes MH, Jaffe D, Johnston IS, Kennedy RC, Koo H, Kravitz S, Kriventseva EV, Kulp D, Labutti K, Lee E, Li S, Lovin DD, Mao C, Mauceli E, Menck CF, Miller JR, Montgomery P, Mori A, Nascimento AL, Naveira HF, Nusbaum C, O'leary S, Orvis J, Pertea M, Quesneville H, Reidenbach KR, Rogers YH, Roth CW, Schneider JR, Schatz M, Shumway M, Stanke M, Stinson EO, Tubio JM, Vanzee JP, Verjovski-Almeida S, Werner D, White O Wyder S, Zeng Q, Zhao Q, Zhao Y, Hill CA, Raikhel AS, Soares MB, Knudson DL, Lee NH, Galagan J, Salzberg SL, Paulsen IT, Dimopoulos G, Collins FH, Birren B, Fraser-Liggett CM, Severson DW: Genome sequence of Ae. aegypti, a major arbovirus vector. Science 2007, 3 I 6(5832): 1718-1723.

5I. Miller BR, Mitchell C): Genetic selection of a flavivirus refractory strains of the yellow fever mosquito Ae. aegypti. Am J Trop Med Hyg 1991, 45:399-407.

52. Gould EA, Clegg CS: Growth, titration and purification of alphaviruses and flaviviruses. In Virology: a practical approach Edited by: Mahy BWJ. Oxford: ILR Press; | 99 |:43-69.

53. Putnak R, Barvir DA, Burrous JM, Dubois DR, D'Andrea VM, Hoke $\mathrm{CH}$, Sadoff JC, Eckels $\mathrm{KH}$ : Development of a purified, inactivated, dengue- 2 virus vaccine prototype in Vero cells: immunogenicity and protection in mice and rhesus monkeys. J Infect Dis 1996, 174(6): I I76-I I 84.

54. Ramasamy MS, Sands M, Kay BH, Fanning ID, Lawrence GW, Ramasamy R: Anti-mosquito antibodies reduce the susceptibility of Ae. aegypti to arbovirus infection. Med Vet Entomol 1990, 4(I):49-55.

55. Rutledge LC, Ward RA, Gould DJ: Studies on the feeding response of mosquitoes to nutritive solutions in a new membrane feeder. Mosq News 1964, 24:407-419.

56. Bradford M M: A rapid and sensitive method for the quantitation of microgram quantities of protein utilizing the principle of protein-dye binding. Anal Biochem 1976, 7(72):248-254
57. Laemmli UK: Cleavage of structural proteins during the assembly of the head of bacteriophage T4. Nature 1970, 227(5259):680-685.

Publish with Bio Med Central and every scientist can read your work free of charge

"BioMed Central will be the most significant development for disseminating the results of biomedical research in our lifetime. "

Sir Paul Nurse, Cancer Research UK

Your research papers will be:

- available free of charge to the entire biomedical community

- peer reviewed and published immediately upon acceptance

- cited in PubMed and archived on PubMed Central

- yours - you keep the copyright 